\title{
Outside-in TOT Procedure: Three-Years Experience with 175 Cases \\ Dıştan-İçe TOT Operasyonunda 3 Yıllık Deneyim:175 Olgu
}

\author{
Selim AFŞAR *, Mustafa EROĞLU **, Birol DURUKAN **, Hacer Hicran BEYCA *** \\ * Tekirdağ Devlet Hastanesi \\ ** Zeynep Kamil Kadın ve Çocuk Hastalıkları Eğitim ve Araştırma Hastanesi \\ *** Bezmi Alem Vakıf Gureba Üniversite Hastanesi, Aile Hekimliği Servisi
}

\section{ABSTRACT}

Aim: The aim of this study is to evaluate the surgical outcomes and complications of transobturator tape (TOT) procedure.

Material and Methods: In this study, 175 patients who were undergone TOT procedure due to pure stress urinary incontinence (SUI) or mixt urinary incontinence (MUI) from 2011-2014 and examined at $1^{\text {st }}$ and $3^{\text {rd }}$ postoperative months with physical examination and stress tests were evaluated retrospectively.

Results: All of the patients were multiparous and the median age was $50.0 \pm 11.3$ years. Sixty-eight $(38.8 \%)$ of the patients were postmenopausal and sixty-two (35\%) of the patients who had TOT operation had extra surgery. One patient is complicated with bladder perforation. Only one patient had blood transfusion requirement due to TOT operation. Intraoperative bleeding more than $200 \mathrm{ml}$. is seen in 6 patients. Four patients had vaginal fornix perforation. Three patients had developed perineal pain. De-novo urge incontinence was seen in 8 patients in the postoperative period and was successfully treated with anticholinergic drugs. Mesh removals and reconstruction of vaginal mucosa were done for 6 patients who had vaginal erosions. The objective and subjective cure rates were found to be $87.4 \%$ and $82.8 \%$, respectively.

Conclusion: The use of mid-urethral synthetic slingis the first-choice of the surgical treatment of SUI nowadays. The main reasons for this are low complication rates due to surgical technique, the use of good quality materials, short operation time, and short hospital stay.

Keywords: transobturator tape, outside-in, outcomes, complications.

\footnotetext{
İletişim Bilgileri:

Sorumlu Yazar: Op. Dr. Selim Afşar

Yazışma Adresi: Tekirdağ Devlet Hastanesi, Tekirdağ

Tel: +90 5336628495

Fax: +90282 2625355

E-mail: selimafsar@yahoo.com

Makalenin Geliş Tarihi: 07.05.2014

Makalenin Kabul Tarihi: 04.08.2014
}

\section{ÖZET}

Amaç: Bu çalışmanın amacı transobturator teyp (TOT)operasyonunun etkinliğinin ve komplikasyonlarının değerlendirilmesidir.

Gereç ve Yöntemler: Bu çalışmada 2011-2014 yılları arasında saf stres ürinerinkontinans(SÜI)veya mikstürinerinkontinans(MÜi) nedeniyle dıştan-içe TOT operasyonu uygulananve postoperatifdönemde 1. ve 3. ayda kontrol muayenesi ve stres testleri yapılarak değerlendirilen175 hasta retrospektifolarak incelendi.

Bulgular: Hastaların tamamı multipar veyaş orta-

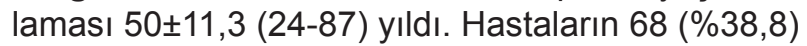
tanesi postmenopozal dönemde ve 62 (\%35)'indeek cerrahi uygulanmıştı.Bir hastada mesane perforasyonuoluşmuştu. TOT operasyonuna bağlı kan transfüzyonu gereksinimi sadece 1 hastada gerekli olmuştu. İntraoperatif 200ml üzerinde kanama 6 hastada izlendi. Vajinal forniksperforasyonu 4 vakada izlenmişti. Perineal ağrı 3 olguda ortaya çıkmıştı. De novourgeinkontinanspostoperatif 8 hastada izlenmişti ve bu hastalara antikolinerjik tedavisiuygulanmıştı. Vajinal erozyon görülen 6 hastada mesh eksize edildi ve vajen mukozası tekrar sütüre edildi. Objektif ve sübjektif kür oranları sırasıyla $\% 87,4$ ve $\% 82,8$ olarak bulundu.

Sonuç: Mid-üretralsentetik slingkullanımı Süi cerrahi tedavisinde günümüzde ilk seçenek olarak tercih edilmektedir. Kaliteli malzeme kullanımı ve cerrahi teknik sayesinde komplikasyon oranının düşük olması, operasyon süresinin kısa oluşu ve hastanede kalış süresinin az olması bunda esas etkili olan faktörlerdir.

Anahtar Kelimeler: transobturatortepy TOT, dıştan-içe, etkinlik, komplikasyonlar. 


\section{INTRODUCTION}

In the surgical treatment stress urinary incontinence (SUI), mid-urethral synthetic slings (MUSS) are preferred as the first choice lately (1). The logic behind the MUSS insertion operations depends on "the integral theory" of Petros and Ulmsten in 1990, "hammock theory" of DeLancey in 1994 as an alternative to the integral theory, which describes the anatomic and functional principles of how to maintain urethral pressure against bladder and intra-abdominal pressures $(2,3)$. Delorme et al. (2001) described outside-in transobturator tape (TOT) procedure (4), as an alternative to firstly applied tension free vaginal tape (TVT) procedures. The objective and subjective cure rates of TOT procedure were reported to be $83-98 \%$ and 77 $88.7 \%$, respectively (5-8). Beside the benefits, we believe that complication reports of TOT procedure should be encouraged in order to establish good understanding of this surgical method. For this purpose, we aimed to report the efficacy and complications on patients whom we applied the TOT procedure.

\section{MATERIAL AND METHOD}

This retrospective study included 175 patients, who were applied outside-in TOT procedure between years 2001 and 2004 with the diagnosis of pure SUI and MUI. After obtaining complaints and medical history, all patients were physically examined in detail. In pelvic examination patients with positive stress test and Q-tip test $>30^{\circ}$ were chosen as a candidate for TOT procedure. Patients with pure urge incontinence, neurological disease, and anti-thrombotic medication were excluded from the study. All patients were obtained informed consents; and operated using TOT material of Obtryx ${ }^{\mathrm{TM}}$. Outside-in TOT procedure was applied as it was reported (4). The choices of anesthesia were mostly spinal block (87\%), and general anesthesia (13\%). Intra operative cystoscopy was applied to one patient. All patients were evaluated at the first and the third month postoperatively with detailed pelvic examination and stress test. Treatment failure was defined as patients with ongoing incontinence complaints. Subjective cure was defined as patients with positive stress test but no complaints of urinary incontinence. Objective cure was de- fined as patients with negative stress test and no complaints of urinary incontinence. Operational success and perioperative complications were also noted.

\section{FINDINGS AND RESULTS}

All patients were multiparous with the mean (min-max) age $50.0 \pm 11.3(24-87)$ years. Patients in the postmenopausal period were $38.8 \%(n=68)$, and in the peri-menopausal period were $61.2 \%(n=107)$. TOT was solely applied to $65 \%$ of the patients $(n=84)$. Additional intra-operative procedures beside TOT were applied to $35 \%$ of the patients $(\mathrm{n}=62)$ including LeFort Colpocleisis $n=14$, abdominal hysterectomy $n=11$, vaginal hysterectomy $n=11$, tubal sterilisation $n=10$, cystocele repair $n=8$, rectocele repair $n=5$, laparoscopic hysterectomy $n=4$ (Figure 1).

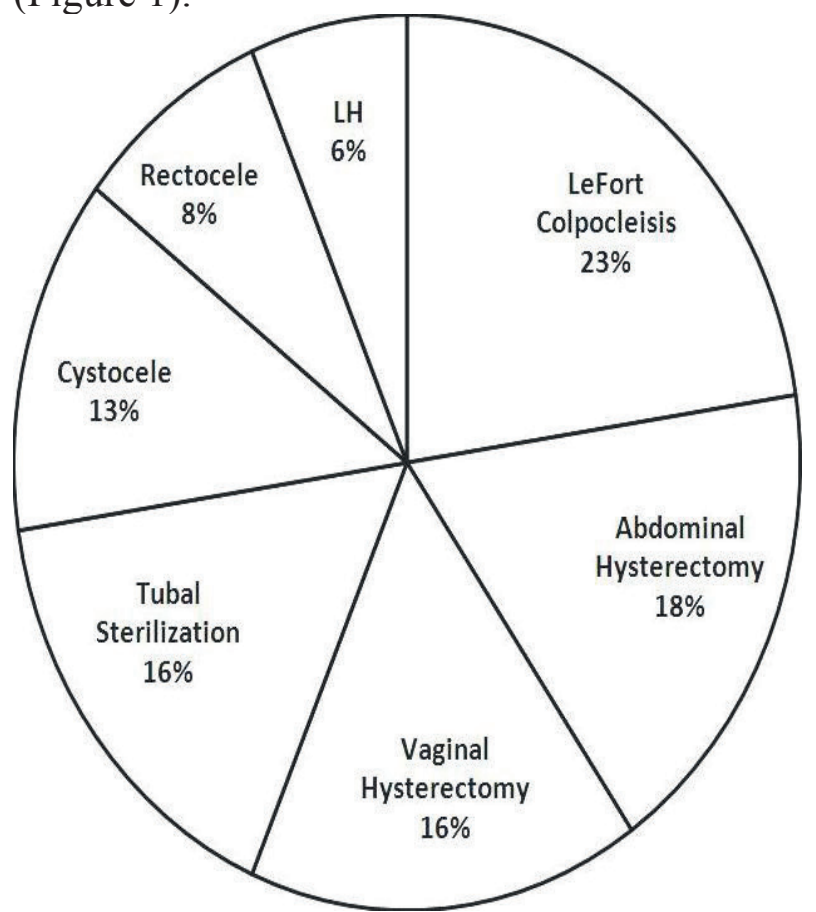

Figure 1. Additional surgery beside TOT ( $\mathrm{n}=62$, LH: Laparoscopic hysterectomy)

Per-operative complications were fairly rare including blood transfusion in only TOT applied one patient, and concomitant abdominal hysterectomy applied two patients. More than $200 \mathrm{cc}$ of intraoperative bleeding from TOT incision site was observed in 6 patients, complications were demonstrated in Table 1. Bladder catheter was removed at the $6^{\text {th }}$ postoperative hours in patients with spinal anesthesia, $24^{\text {th }}$ hour in patients with general anesthesia, $10^{\text {th }}$ day in a patient with bladder perforation. Urinary retention was not seen in any of the patients. 
Table 1. Short term complications and management in operated patients.

\begin{tabular}{|c|l|l|}
\hline$(\mathbf{n})$ & \multicolumn{1}{|c|}{ Complication } & \multicolumn{1}{c|}{ Management } \\
\hline $\mathbf{6}$ & $>200 \mathrm{ml}$ bleeding from TOT site & Hemostasis with compression \\
\hline $\mathbf{4}$ & Vaginal perforation & Repair with sutures \\
\hline $\mathbf{8}$ & De novo urge incontinence & Anti-cholinergic drug prescription \\
\hline $\mathbf{3}$ & Perineal pain & Analgesics and cold application \\
\hline $\mathbf{6}$ & Vaginal erosion & Excision and repair with sutures \\
\hline $\mathbf{1}$ & $\begin{array}{l}\text { Bladder } \\
\text { perforation }\end{array}$ & $\begin{array}{l}\text { Repair with sutures,control cystoscopy and follow-up 10 days with } \\
\text { bladder catheter }\end{array}$ \\
\hline
\end{tabular}

\section{Treatment Success and Failure}
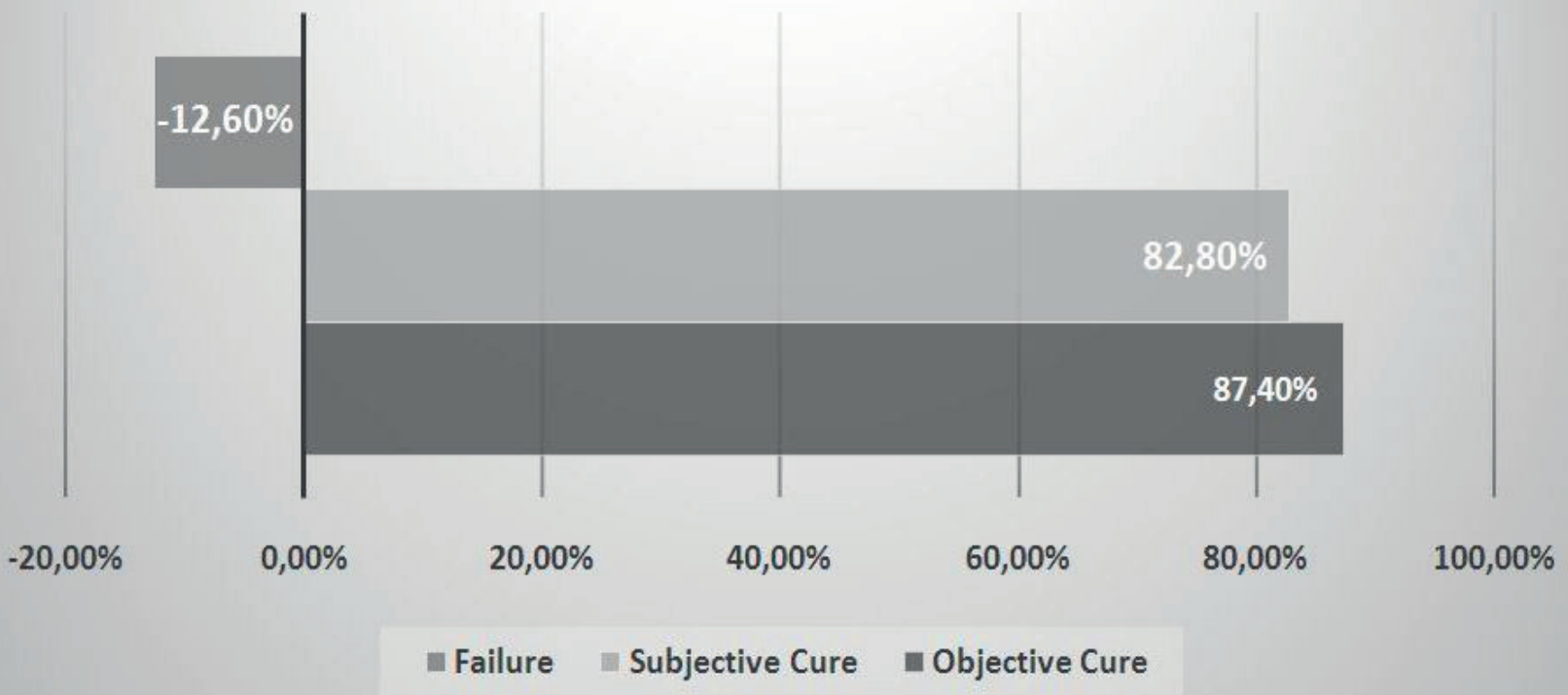

Figure 2. Ratios of treatment failure, subjective and objective cure in TOT.

Treatment failure ratio was found to be $12.6 \%$ Objective cure ratio was $87.4 \%$ and subjective cure ratio was $82.8 \%$ (Figure 2).

\section{DISCUSSION}

In treatment of patients with SUI, TOT procedure became the preferred treatment modality because of its relatively short operation time, easy application, high success, and low complication rate $(1,9)$. In a meta-analysis of Lattheet al., TOT procedure was found to have reliable outcome with low morbidity (10). In our study complication rate is $16 \%$, similar to that of previously reported (11). It was reported that bladder perforation in TOT procedure is lower than in TVT, and does not differ between "outside-in" and "inside-out" TOT procedures $(10,12,13)$.In this study, we experienced the single case of bladder injuryin a postmenopausal patient with a history of hysterectomy during the time of the right arm insertion., and treated with primary repair of the bladder and subsequently leaving the bladder catheter inside for 10 days. There are case reports of blad- der injury after TOT procedures (13-14). No other patients were routinely applied cystoscopy. The majority of the literature supports insertion of a TOT, both outside-in and inside-out techniques, without the need of cystoscopy(15). We observed that de-novo urge symptoms were as low as $4.5 \%$, similar to previous reports and these symptoms resolve with the administration of anti-cholinergic drugs(16). Perineal pain following TOT was reported to be $2-5 \%$ (12). Our results demonstrated $1.7 \%$ of patients experienced perineal pain, which has a short course and spontaneously resolve afterwards. Lateral vaginal wall tears occurred in four patients, unrelated to insertion technique and were mainly due to the thin and fibrosed vaginal wall, reflecting the need for more surgical dissection (17). Vaginal erosion, the long term complication of TOT procedure, was usually attributed to the surgical method and the sling material used (18). Macro-pore mesh was used in all of our patients, and vaginal erosion rate was found to be $3.4 \%$ $(n=6)$, which was also similar to previously reported (10). Our results indicate $87.4 \%$ objective cure rate and $12.6 \%$ failure rate, which de- 
monstrates high efficacy and is concordant with the literature (10). In conclusion, MUSS usage in SUI was preferred as first line treatment option in nowadays. We think that short operation time and hospital stay were the most important factors in this choice as well as low morbidity with the utilization good surgical practice and good quality mesh material.

\section{REFERENCES}

1. Fong ED, Nitti VW. Reviewarticle: Mid-urethralsyntheticslingsforfemalestressurinaryincontinence. BJU Int 2010;106:596-608.

2. Petros PE, Ulmsten UI. An integral theory of femaleurinaryincontinence. Experimentalandclinicalconsiderations. ActaObstetGynecolScandSuppl 1990; 153: 7-31.

3. DeLancey JO. Structuralsupport of theurethra as it relatestostressurinaryincontinence: thehammockhypothesis. Am J ObstetGynecol 1994; 170: 1713-23.

4. Delorme E. Transobturatorurethralsuspension: mini-invasiveprocedure in thetreatment of stressurinaryincontinence in women. ProgUrol2001, 11(6):1306-1313.

5. Liapis A, Bakas P, Creatsas G. Monarcvs TVT-O forthetreatment of primarystressincontinence: a randomizedstudy. IntUrogynecol J PelvicFloorDysfunct 2008; 19: 185-90.

6. Abdel-Fattah M, Ramsay I, Pringle S, Hardwick $\mathrm{C}$, Ali $\mathrm{H}$. Evaluation of transobturatortapes (E-TOT) study: randomisedprospectivesingle-blindedstudycomparing inside-out vs. outside-in transobturatortapes in management of urodynamicstressincontinence: shorttermoutcomes. Eur J ObstetGynecolReprodBiol 2010; 149: 106-11.

7. But I, Faganelj M. Complicationsandshort-termresults of twodifferenttransobturatortechniquesforsurgicaltreatment of womenwithurinaryincontinence: a randomizedstudy. IntUrogynecol J PelvicFloorDysfunct 2008; 19: 857-61.

8. Takeyama M, Fukumoto Y, Noma M, Yamamoto $\mathrm{K}$, Yamanaka M, Uesaka Y. A prospectivestudyabout trans-obturatortapeprocedureswiththetapefromtheGynecare TVT deviceand a C-shapetunnellercomparisonbetweenoutside in and inside outprocedures. Available at: http://www.urotoday.com. AccessedJune 2010.

9. Costa P, Grise P, Droupy S, Monneins F, Assenmacher C, Ballanger P, Hermieu JF, Delmas V,
Boccon-Gibod L, Ortuno C. Surgicaltreatment of femalestressurinaryincontinencewith a trans-obturatortape (TOT) Uratape: shorttermresults of a prospectivemulticentricstudy. EurUrol 2004; 46: 102-7.

10. P. Latthe, R. Foon, P. Toozs-Hobson. Transobturatorandretropubictapeprocedures in stressurinaryincontinence: a systematicreviewand meta-analysis of effectivenessandcomplications.BJU Int. 2010;106(1):68-76.

11. Arrabal-Polo MÁ, Palao-Yago F, Zuluaga-Gómez A, López-León VM, Merino-Salas S, Lahoz-García C, Arrabal-Martín M. Complicationsfromtheplacement of a tension-freesuburethralslingusingthetransobturatorandretropubicmethodsfortreatment of femaleurinaryincontinence. Urollnt. 2012;89(1):97102

12. Krauth JS, Rasoamiaramanana $\mathrm{H}$, Bartela $\mathrm{H}$, Barrier PY, Grisard- Anaf M, Lienhart J, Mermet J, Vautherin R, Frobert JL. Suburethraltapetreatment of femaleurinaryincontinencemorbidityassessement of the trans-obturatorrouteand a newtape (I-STOP): A multicentreexperimentinvolving 604 cases. EurUrol 2005; 47: 102-7.

13. Minaglia S, Ozel B, Klutke C, Ballard C, Klutke J. Bladderinjuryduringtransobturatorsling. Urology 2004; 64: 3761-2.

14. Smith PP, Appell RA. Transobturatortape, bladderperforation, andparavaginaldefect: a casereport. Int J Urogynaecol2006; 26:1-3.

15. Abdel-Fattah M, Ramsay I, Pringle S, Hardwick C, Tierney J, Ali $\mathrm{H}$ andYoung D.Transobturatorsuburethraltapes in themanagement of urinaryincontinence: success, safetyandimpact on sexual lifeGynecolSurg 2007; 4:267-273.

16. Coyne KS, Sexton CC, Irwin DE, Kopp ZS, Kelleher CJ, Milsom I. Theimpact of overactivebladder, incontinenceandotherlowerurinarytractsymptoms on quality of life, workproductivity, sexualityandemotionalwell-being in men andwomen: Resultsfromthe EPIC study. BJU Int 2008,101(11):1388-1395.

17. Abdel-Fattah M, Ramsay I, Pringle S. Lowerurinarytractinjuriesassociatedwithtransobturatortensionfreevaginaltapeprocedure: a largeretrospectivestudy. BJOG 2006; 113(12):1377-82.

18. Kaelin-Gambirasio I, Jacob S, Boulvain M, Dubuisson JB, Dällenbach P. Complicationsassociatedwithtransobturatorslingprocedures: Analysis of 233 consecutivecaseswith a 27-month follow-up. BMC WomensHealth 2009; 9: 28-34. 